\title{
Psychology of a Changing Paradigm: 40+ Years of High-Pressure Metamorphism
}

\author{
HARRY W. GREEN, II ${ }^{1}$ \\ Institute of Geophysics and Planetary Physics and Department of Earth Sciences, \\ University of California, Riverside, California 92521
}

\begin{abstract}
The story of ultrahigh-pressure metamorphism (UHPM) is a confused mixture of surprising, sometimes spectacular, discoveries and emotional reactions. Surprisingly, the process has been a repeating cycle of disbelief followed by confirmation, with little evidence that the community response in a given cycle has learned from previous cycles. To this writer's understanding, it began in the early 1960s, before the plate-tectonic revolution, when W. Gary Ernst determined experimentally that the blue amphibole, glaucophane, is stable only at low temperatures and elevated pressures. The implication that glaucophane-bearing rocks, such as those of the Franciscan Complex of northern California, could have been rapidly carried to high pressure and returned to the surface equally rapidly was rejected as impossible. The advent of plate tectonics provided a conceptual answer to the conundrum, but resistance remained, and the concept of tectonic overpressure was invented to explain away the depths implied by experimental results. Despite both theoretical and practical demonstration that this concept is invalid, the concept continues to resurrected to this day. In the $1970 \mathrm{~s}$, the development of the technique of thermobarometry brought a welcome ability to infer the pressure/temperature from which kimberlite xenoliths had been brought to the surface. However, application of the technique to garnet peridotites in the field, again led by Ernst, brought resistance from those for whom depths exceeding $120 \mathrm{~km}$ did not fit readily into their previous interpretations. Subsequent discoveries of coesite in the 1980s and diamonds in the 1990s in continental-collision terranes met with similar disbelief initially, and microstructural evidence for exhumation from depths of hundreds of $\mathrm{km}$ in the same terranes experienced the same reception. Piece by piece, the general community has now largely accepted these discoveries, but a new claim of rocks perhaps from the lower mantle is experiencing renewal of the cycle. This paper presents some highlights of the discoveries during this period, and attempts to understand some of the human aspects of this slow but not-so-quiet revolution.
\end{abstract}

\section{Introduction}

THE PROCESS BY which science advances is a conservative one. That is, each step of the way involves documentation that the new information is reproducible and consistent with the existing body of knowledge. For most day-to-day operations of science, this approach is reasonable and successful; inaccurate observations and incorrect deductions are weeded out, and accurate observations and deductions are added to the fabric of knowledge. However, when new observations or arguments do not fit into the existing paradigm, there is a strong tendency for them to be rejected by the scientific

${ }^{1}$ Email: harry.green@ucr.edu community. The larger the shift of paradigm required to accommodate the new information, the more harsh and emotional is likely to be the rejection. This article provides a brief chronicle of the history of ultrahigh-pressure metamorphism. The shift in paradigm directly involved is not a particularly large one, but it is embedded in the much larger shift involved in the acceptance of plate tectonics by the Earth Science community; it shows that a segment of a scientific community (in this case metamorphic petrology) can be left behind during a scientific revolution because the underlying assumption upon which the old paradigm for that segment was based was not recognized as a holdover from the fixist views of the 19th century and the first two-thirds of the 20th century. 


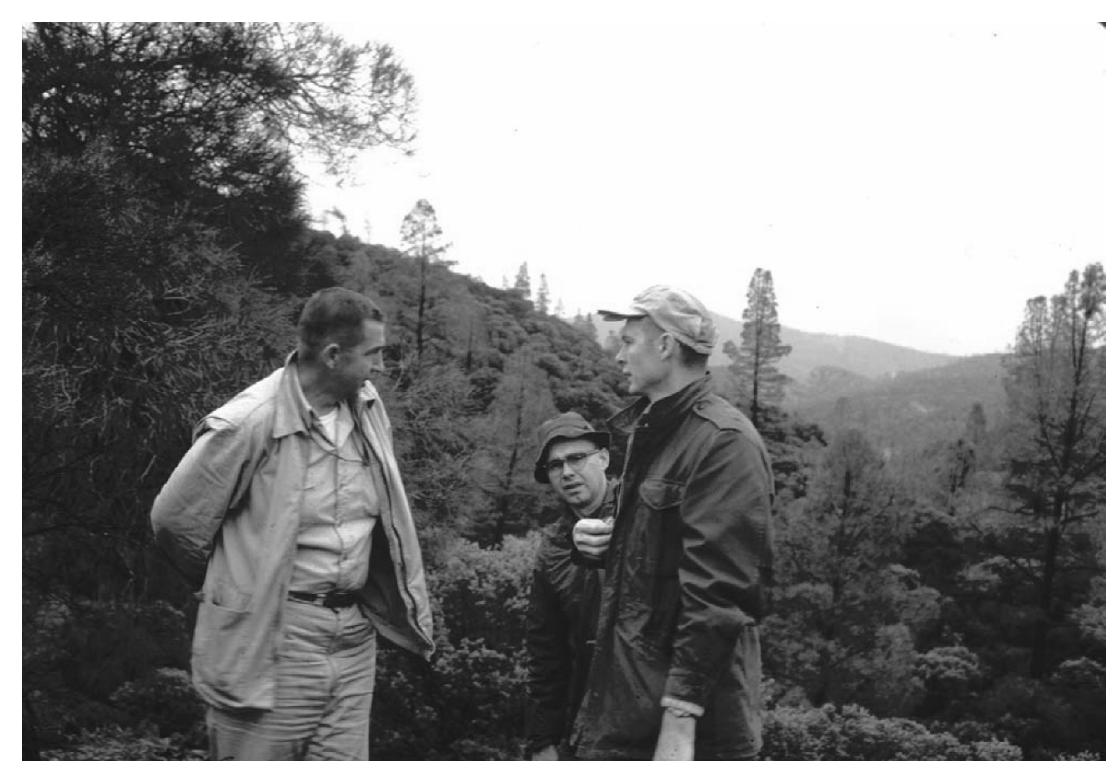

FIG. 1. Gary Ernst (right) in the field in the Franciscan complex of California circa 1962 with Robert Coleman (left) and Arden Albee. Photo by Y Seki.

\section{The Beginning: Franciscan Paradox}

In the early 1960s, revolution was in the air in the Earth Sciences. Periodic reversal of Earth's magnetic field had been discovered but was not yet fully accepted (e.g., Opdyke and Runcorn, 1956). Nevertheless, application of paleomagnetism by the early leaders in the field was pointing (Collinson and Runcorn, 1960) to similar continental movements in the past, as had been envisioned by Wegener $(1912,1923)$ and others based on physiography of the globe and geological "fits" across ocean basins (c.f. Holmes, 1965). Harry Hess had advanced the theory of sea-floor spreading to explain ocean ridges (see review in Hess and Revelle, 1963), but the work of Vine and Matthews (1963), Tuzo Wilson (1963, 1965), and the full explosion of plate tectonics (Isaacs et al., 1968; Le Pichon, 1968; Morgan, 1968) were still to come.

A young assistant professor at UCLA, W. G. Ernst (Fig. 1), was conducting experiments on the stability relations of glaucophane, a sodium amphibole that is a relatively rare mineral but is prominent in blueschists of the Franciscan Complex of central and northern California. This formation was of considerable interest because of its chaotic internal structure, including randomly mixed "knockers" (with sizes from meters to hundreds of meters or more), of widely varying lithology and metamorphic grade in a very fine-grained matrix. During 19611963 , the present author was employed as an undergraduate assistant, separating glaucophane and other minerals from the rocks with heavy liquids. Ernst found, to his consternation, that the stability of glaucophane was confined to low temperatures and, for that time, high pressures (Ernst, 1963). As a consequence, the straightforward explanation of the metamorphic history of glaucophane-bearing rocks was that: (1) somehow they were transported to sufficient depth to explain the pressures implied by his experiments $(0.7-0.8 \mathrm{GPa})$; and (2) they then were returned to the surface sufficiently rapidly that they never warmed to the temperatures expected for such depths. Had they not been returned to the surface quickly, the glaucophane would have broken down to chlorite and other minerals and the evidence of their rapid descent would have been lost (Ernst, 1965). Thus, the simple experimental result that glaucophane stability is limited to low temperatures but elevated pressures implied not only uncomfortably high pressures but also uncomfortably high descent and ascent rates, all of which violated the then-current paradigm.

The reaction of the geological community to these laboratory results was predictable: Either the experimental results had to be incorrect or 
misinterpreted, or their application to Earth was flawed. The implied depths were unacceptable because surficial geology was viewed as being essentially separated from Earth's interior by isostasy-continental rocks are light and float on mantle rocks that are more dense. The descent and ascent rates were unacceptable because they seemed much too rapid to be consistent with geological processes. At that time, metamorphosed sedimentary rocks were thought to be subjected to elevated pressures by burial beneath more sediments and to be exhumed from depth by erosion; both of these processes were too slow to allow the temperatures to remain low enough for glaucophane to be grown stably and then preserved by rapid cooling. Demonstration that the conditions of experimentation could not be significantly in error was relatively easy to achieve. Nevertheless, the inferred geological implications of the results were unacceptable. It was realized that if the error lay in the pressure (depth) implication, then the burial and exhumation rates would automatically be resolved.

At the same time (late 1950s, early 1960s), another, seemingly unrelated, subject was of interest to geologists concerned with metamorphism. In the late 19th century, thermodynamic understanding of chemical equilibrium in heterogeneous systems had been put on a firm footing by J. Willard Gibbs (e.g. Gibbs, 1948). However, one of the loose ends of Gibbs's work was the question of what happens to thermodynamic equilibrium under conditions of nonhydrostatic stress. Gibbs himself showed that his concept of chemical potential was not a single-valued global function under nonhydrostatic stress, and this question had been revisited but not resolved by a number of scientists in both geology and physics during the first half of the 20th century. There was a flurry of activity in this subject in the geological literature of the 1950s and early 1960s, culminating in a confrontation in print between W. B. Kamb (1961a, 1961b) and G. J. F. MacDonald (1961) in which MacDonald's theory of nonhydrostatic thermodynamics was shown to be flawed and Kamb's vindicated. We shall return to this subject below; suffice it to say for now that interpretation of the thermodynamic state under nonhydrostatic stress in the early 1960s was not well understood.

The basic problem is that under hydrostatic (isotropic) stress, pressure is a scalar quantity and Gibbs's famous equation for the free energy of a chemical component can be expressed as:

$$
\mu=\mathrm{U}+\mathrm{PV}-\mathrm{TS},
$$

where $\mu$ is the Gibbs (free) energy per mole or the chemical potential, $\mathrm{U}$ is the partial molar internal energy of the component, $\mathrm{P}$ is pressure, $\mathrm{V}$ is the partial molar volume of the component, $\mathrm{T}$ is the absolute temperature, and $\mathrm{S}$ is the partial molar entropy of the component. The critical question in the present context is "What happens to this equation when the scalar parameter $\mathrm{P}$ representing pressure (and requiring one number to describe it) becomes a nonhydrostatic stress and therefore a second-rank tensor (requiring six numbers to describe its magnitude and orientation)?" In the early 1960s, it was thought by many in the geological community that one of the possible answers to this question was that one could generalize pressure in the following way:

$$
\mathrm{P}=\left(\sigma_{1}+\sigma_{2}+\sigma_{3}\right) / 3,
$$

where $\sigma_{1}, \sigma_{2}$, and $\sigma_{3}$ are the three principal stresses; hence the effective pressure is assumed to be the average of the three principal stresses.

It was well known that Earth is a dynamic body and that, in general, the pressure at depth during mountain building must be nonhydrostatic. It was therefore argued that if the horizontal stresses were sufficiently high during tectonic deformation, then the apparent pressure as indicated by the minerals present could be different from that calculated assuming:

$$
\mathrm{P}=\rho g h,
$$

where $\rho$ is the density of the overlying rock, $g$ is the acceleration of gravity, and $h$ is the height of the overlying rock. Therefore, if $\mathrm{P}$ were given by (2) rather than by (3) as assumed by Ernst, and if the horizontal stresses were sufficiently high, the vertical stress could be low, and the depth of burial could have been much less than that implied by Ernst. Voilá: the experimental results could be correct but their application to Earth was invalid. The difference between the pressure one would calculate from (2) and that calculated from (3) was termed "tectonic overpressure" (see Brace et al., 1970 and references therein). Whew!! The paradigm was saved.

Undaunted, Ernst enlisted one of the leading rock mechanics experts of the day, W. F. Brace, and in Brace's laboratory at MIT they demonstrated that in order to explain away Ernst's implications by this argument, the strength of Franciscan rocks during prograde metamorphism would have had to be 
greater than the room temperature crushing strength of the rocks in the laboratory. In short, they showed that quantitatively the argument was grossly inadequate. Their diplomatically worded conclusion was that to explain the presence of blueschists (glaucophane-bearing rocks) by tectonic overpressure, "It would be necessary to have rapid, geologically unrealistic strain rates, for fluid to be absent [or almost absent], and to have temperatures insufficient for the facies to develop" (Brace et al., 1970). Despite this absolutely clear repudiation of the concept of tectonic overpressure on a practical basis, the concept has reappeared over and over again to this day as the evidence for greater and greater depths of equilibration of rocks has been assembled.

The reader should note the date of the Brace et al. (1970) paper. That paper appeared two years after the plate tectonics revolution burst forth undeniably onto the world stage (1968), carrying with it the easy answer to the dilemma presented to the metamorphic community by Ernst (1963). The easy answer is that Ernst was correct; plate tectonic theory easily explained the Franciscan Complex as sediments carried down ("subducted," in modern terminology) to previously unbelievable depths (20$50 \mathrm{~km}$ ) along the interface between the Pacific and North American plates where they were metamorphosed at high pressures and low temperatures, and then returned back up that interface at comparable rates. In the process of exhumation they were chaotically deformed, mixing rocks of a wide variety of metamorphic grades, and plastered onto the western margin of North America.

\section{Tectonic Overpressure: A Failed Concept}

Advances in nonhydrostatic thermodynamics over the last 40 years have shown that under nonhydrostatic stress, stability of a phase is determined not by the total stress state but by the local normal stress across a specific interface. This has been verified both theoretically (e.g., Kamb, 1961a; Green, $1970,1980,1986)$ and experimentally (Vaughan et al., 1984; Green, 1986). The experimental work demonstrated that polycrystalline specimens of $\mathrm{Mg}_{2} \mathrm{GeO}_{4}$ olivine subjected to nonhydrostatic stress within the stability field of the high-pressure spinel polymorph undergo the phase transformation preferentially on interfaces of higher normal stress. In particular, under the special conditions in which the stress state straddled the phase boundary as determined under hydrostatic stress, those surfaces whose normal stress placed them in the spinel stability field experienced nucleation and growth of the spinel phase, whereas those surfaces whose normal stress placed them in the olivine field experienced recrystallization to new crystals of the olivine phase (Fig. 2). Thus, the very idea of tectonic overpressure is faulty because there is no such thing as global equilibrium under nonhydrostatic stress. As a consequence, stable growth of glaucophane (or any other high-pressure mineral) can occur only on interfaces whose normal stress reaches the glaucophane stability field, and any relaxation of that normal stress would cause the glaucophane to be consumed unless the temperature was reduced quickly to stop reaction. Coupled with current knowledge that under metamorphic conditions rocks cannot support large stresses except at very high strain rates (essentially the conclusion reached by Brace et al., 1970), it follows that under natural conditions nonhydrostatic stress can perturb growth conditions of minerals only marginally. This conclusion remains valid despite the various attempts that have been made in the more recent past to revive the concept of tectonic overpressure. No amount of theoretical calculations can make rocks in a metamorphic environment stronger, nor can they remove the experimental observations of Figure 2.

\section{Thermobarometry}

In the early 1970s, a revolutionary paper by F. R. (Joe) Boyd (1973) showed that the partitioning of elements between pyroxenes of garnet-bearing peridotite in high-pressure experiments is significantly pressure dependent. As a consequence, comparison of the chemical composition of peridotite xenolith minerals from diamond-bearing kimberlite pipes with phases synthesized in experiments conducted under known conditions can enable calculation of the pressure and temperature from which each xenolith was plucked. Analysis of a suite of xenoliths from the same pipe allows determination of a mineralogical cross section of the mantle and the associated thermal profile at the time of eruption. The result showed that kimberlite magmas and many of their xenoliths come from depths greater than approximately $200 \mathrm{~km}$ (e.g., Green and Gueguen, 1974), fully consistent with the presence of diamonds (that would be stable only at pressures in excess of $4 \mathrm{GPa}=$ depths exceeding approximately $120 \mathrm{~km}$ at mantle temperatures). 


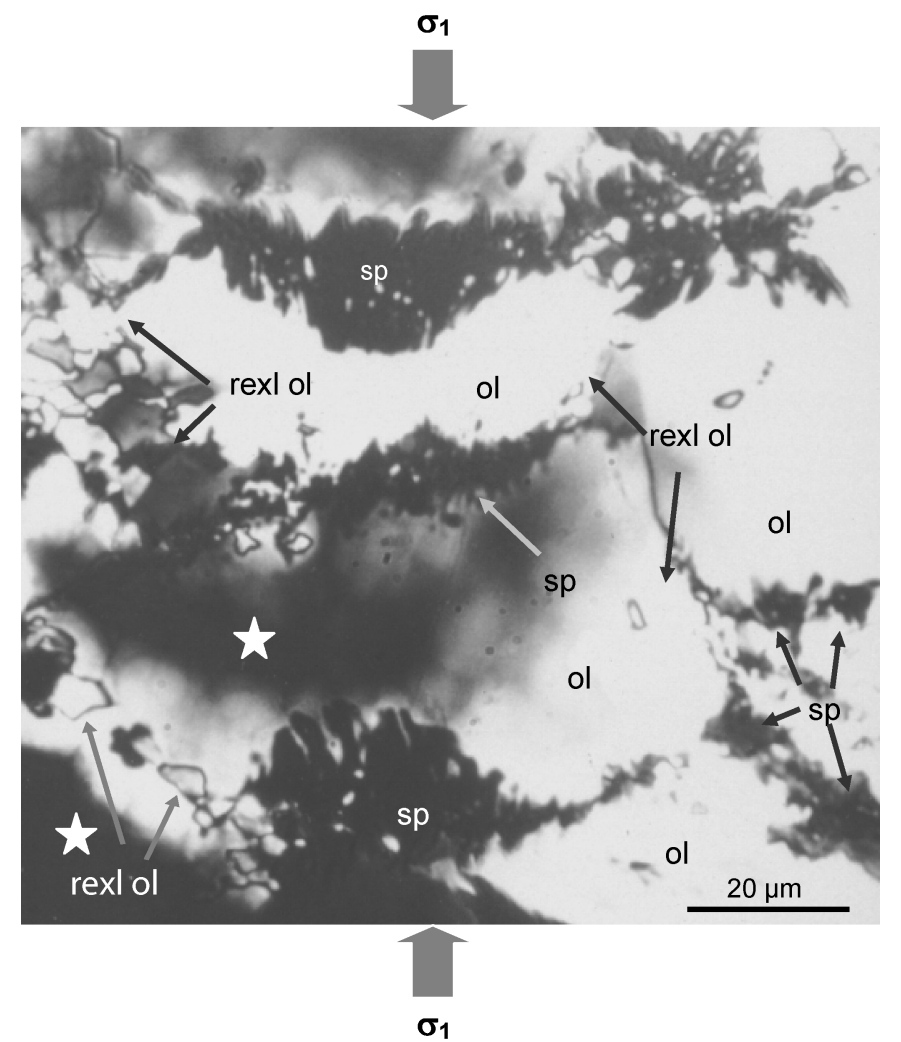

FIG. 2. Optical micrograph of a very thin section (0-2 $\mu \mathrm{m}$ thick) of a polycrystal of $\mathrm{Mg}_{2} \mathrm{GeO}_{4}$ olivine (ol) undergoing transformation to the high-pressure spinel polymorph under nonhydrostatic stress. Conditions of the experiment were such that the normal stress on grain boundaries approximately perpendicular to the maximum principal stress, $\sigma_{1}(\mathrm{~N}-\mathrm{S}$ in photo), was in the spinel stability field and the normal stress on grain boundaries approximately perpendicular to the minimum principal stress, $\sigma_{3}$ (E-W in photo), was in the olivine stability field. Note that the first set of grain boundaries are populated with newly grown spinel crystals (sp) that in many cases can be seen to be growing fastest parallel to $\sigma_{1}$, whereas the second set of grain boundaries show recrystallization of olivine (rexl ol). Stars denote holes in the thin section produced during ion milling. Modified after Figure 4 of Vaughan et al. (1984).

Once again, the pioneer in applications to field geology was Ernst, who applied this "pyroxene geotherm" technique to the Alpe Arami garnet peridotite of the Swiss Alps, with the astounding result that it had last equilibrated at conditions of $\sim 4.0$ $\mathrm{GPa}$ (Ernst, 1978), implying that this alpine peridotite in a continental collision environment had somehow been incorporated into the continental crust and brought to the surface without losing its "memory" of depths approximating that for diamond stability. Once again, conventional wisdom found these results unacceptable; the conclusion was that this new technique must still contain flaws; detractors were confident that subsequent refinement of thermobarometry would surely yield lower pressures for these rocks. In fact, the contrary happened; successive reanalyses of this massif yielded $\sim 5.0$ GPa (Medaris and Carswell, 1990) and $~ 5.9 \mathrm{GPa}$ (Paquin and Alther, 2001a). Only the results of Nimis and Trommsdorff (2001a, 2001b) yielded lower pressures than determined by Ernst (1978), and the results of that study have been criticized for selection of data that effectively eliminated the high-pressure signal (e.g., Paquin and Alther, 2001b). We will return below to discussion of the depth from which the Alpe Arami massif has been transported to the surface but, in the interest of following approximately a time line, we will first turn to another startling discovery, nearby in the Italian Alps at Dora Maira and shortly thereafter in Norway. 


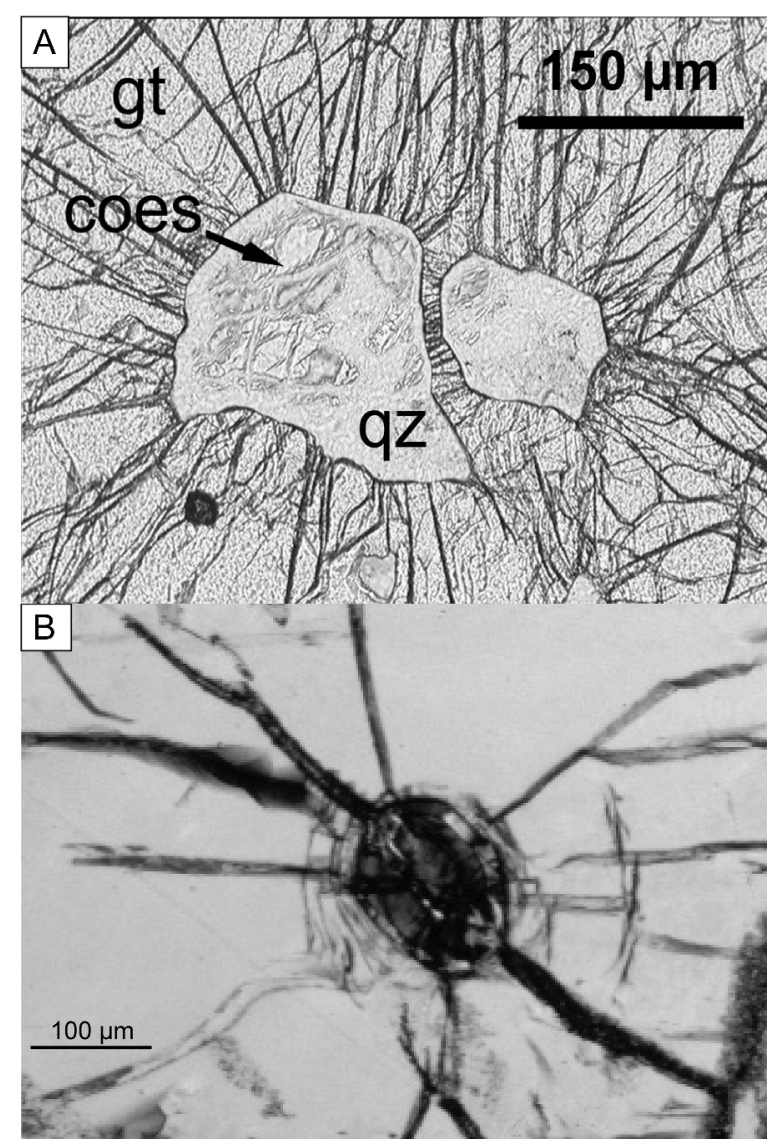

FIG. 3. Photomicrographs of thin sections showing relict coesite enclosed in garnet from Dora Maira, Italy (A) and omphacite from the Western Gneiss Region, Norway (B). Both images also show retrograde quartz and radial fractures in the host mineral generated by expansion as a consequence of partial transformation to quartz during exhumation of the UPHM rocks. Image A courtesy of C. Chopin; image B courtesy of D. Smith.

\section{Coesite in Continental Rocks?}

Natural occurrences of coesite, a high-pressure polymorph of $\mathrm{SiO}_{2}$, were thought to be restricted to meteorite impact craters (Chao et al., 1960), where they were created by transient high pressures during the shock of impact, and to eclogite xenoliths plucked from environments of static high pressure $>3 \mathrm{GPa}$ in the mantle during kimberlite eruptions (Smyth and Hatton, 1977). That image changed suddenly with the discovery of coesite in metamorphosed rocks of continental affinity in the Dora Maira massif (Chopin, 1984), followed very shortly thereafter by similar discovery in eclogite of the Western Gneiss Region of Norway (Smith, 1984). The discovery at Dora Maira (Fig. 3A) was well documented and, for once in this saga, acceptance of the obvious implication of high pressures came reasonably quickly. In Norway, however, others were unable to confirm Smith's discovery (Fig. 3B) and, for reasons baffling to this author, the clear implications of high pressures presented by the unambiguous images in Smith (1984) and subsequent papers by the same author were essentially ignored for 13 years until Alice Wain (1997) found an extensive outcrop area of eclogite displaying coesite inclusions in both garnet and pyroxene, by which time many other pieces of evidence of very high pressures had been found, including diamond farther north in these same gneisses (next section). In the meantime, coesite was first described in the Dabie/ SuLu region of Eastern China (Wang et al., 1989) 
and has since been shown to be rare but ubiquitous in those rocks. Most importantly, in both Norway (Wain, 1997) and China (Ye et al., 2000), coesite has been documented from the quartzofeldspathic country gneisses as well as the mafic eclogites, demonstrating that the coesite is recording bulk metamorphism of the terrane, not simply incorporation of coesite-bearing eclogites into lower-pressure continental material. In the classical UHPM terrane of northern Kazakhstan, coesite was even found exsolving from titanite in marble (Ogasawara et al, 2002). Thus, in this century the ultrahigh-pressure metamorphism problem becomes not "How did these high-pressure rocks get incorporated into the crust?," but rather, "How did continental rocks and sediments get carried to depths greater than $100 \mathrm{~km}$ and returned to the surface?"

\section{Diamonds in Rocks of Continental Affinity}

Returning to the timeline of discovery, once again the world of metamorphic petrology was startled by documentation for the first time in the Western literature of microdiamonds (Figs. 4A and 4B) in metasediments from the Kokchetav massif, northern Kazakhstan (Sobolev and Shatsky, 1990). In this case, the diamonds were so abundant that, despite their small size, their host rocks became ores for exploitation for abrasives. Like Chopin's coesite, there was no denying the existence of the Kazakhstan diamonds, establishing a clear benchmark that rocks of continental composition had been subducted to more than $\sim 120 \mathrm{~km}$ and returned to the surface sufficiently rapidly that the diamonds were not totally consumed by back-reaction to graphite.

Other discoveries of diamonds in continental rocks soon followed in China (Xu et al., 1992) and Norway (Fig. 4C; Dobrzhinetskaya et al., 1995), but neither was generally believed; they both were attributed to contamination, not because there was reason to suspect such a problem, but because it is easy to assert and very difficult to disprove. Indeed, in the case of Norwegian diamonds, the infrared spectra clearly showed them to be fundamentally different from kimberlitic or synthetic diamonds, the only reasonable potential source of contamination, but to have similarities to the metamorphic diamonds of Kokchetav. Both occurrences have since been confirmed in thin section (van Roermund et al., 2002; Yang et al., 2003) (Figs. 4D and 4E). Other diamond localities now known or suspected include Sulawasi (Parkinson and Katayama, 1999), the Urals (Bostick et al., 2003) and the Greek Rhodope (Mposkos and Kostopoiulos, 2001). Most spectacularly, a Kokchetav look-alike has been found in the Erzgebirge of Germany. Of course, it was summarily rejected when first presented at the 1999 Kimberlite Conference (Massonne, 1999), but quickly demonstrated to be real (Fig. 4F; Nasdala and Massonne, 2000).

\section{Onward and Downward}

\section{The Alps}

By the early 1990s, it might seem that the theme of disbelief of indicators of high pressure followed by new discoveries indicating even higher pressures should have begun to settle down. Basically, blueschists were by that time fully accepted as markers of fossil subduction zones worldwide, coesite was accepted in the Dora Maira, and metamorphic diamonds were accepted in northern Kazakhstan. However, complete rejection of coesite and diamond continued unabated in Norway and the discovery of coesite and diamond in China were viewed with great skepticism. Dora Maira and Kokchetav were viewed as isolated curiosities, not the keys to a major new discovery that extensive subduction of continental material can occur during continental collision, followed by rapid return to the surface, essentially up the same subduction zone. Thus, the possibility of subduction to $100-120 \mathrm{~km}$, as indicated by coesite and diamond, was generally accepted, but heavy resistance continued in specific locations where established researchers were reluctant to abandon previously developed interpretations.

Stimulated by a presentation of Stephen Haggerty (University of Massachusetts) during a session of the Spring 1994 meeting of the American Geophysical Union in Baltimore, MD, the present author and his colleagues began an investigation of specimens of the Alpe Arami peridotite (collected in 1973 but never examined in detail) that displayed garnet/pyroxene microstructures similar to those Dr. Haggerty had suggested might indicate very great depth of origin. We already knew that, of the two generations of olivine present in the rocks, the older generation displayed an extremely rare (at that time thought to be unique) lattice preferred orientation (LPO) defined by a maximum of [100] normal to the foliation (Möckel, 1969; Buiskool Toxopeus, 1976, 1977). This LPO had no explanation at that time, 

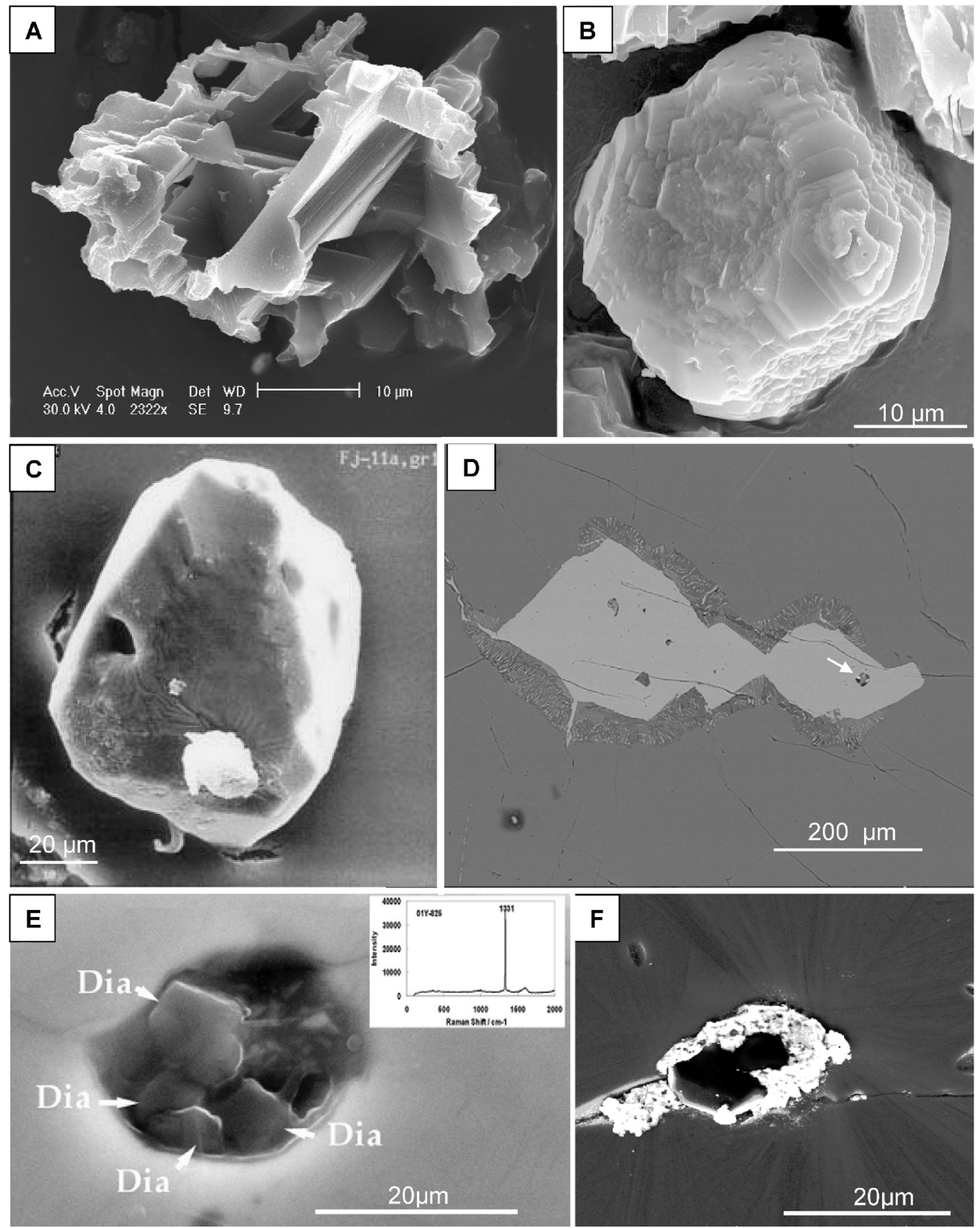

FIG. 4. Scanning electron micrographs of microdiamonds and their microstructural settings. A. Skeletal diamond composed of thin $\{111\}$ plates making up a "house of cards" structure from metasediments; Kokchetav massif, Kazakhstan (see Dobrzhinetskaya et al., 2001). B. Cuboid diamond also composed of octahedral plates, Kokchetav massif, Kazakhstan. C. Microdiamond from metasediments, Fjortoft island, Norway (see Dobrzhinetskaya et al., 1995). D. Spinel within garnet containing a microdiamond-bearing polyphase inclusion (arrow) from peridotite, Fjortoft Island, Norway (see van Roermund et al., 2003). E. Crystal pocket containing diamond and other minerals from Qinling, China; insert shows Raman peak characteristic of diamond (see Yang et al., 2003). F. Microdiamond from Seidenbach Reservoir, Erzgebirge, Germany. The diamond stands out from the polished surface; white material around diamond is metal dug out of the polishing wheel by the diamond. Radial streaks around diamond are left by polishing process (see Massonne, 1999; Nasdala and Massonne, 2000). Images A, B, C, and F are courtesy of L. F. Dobrzhinetskaya; image D is courtesy of H. van Roermund; image E is courtesy of J. Yang. 

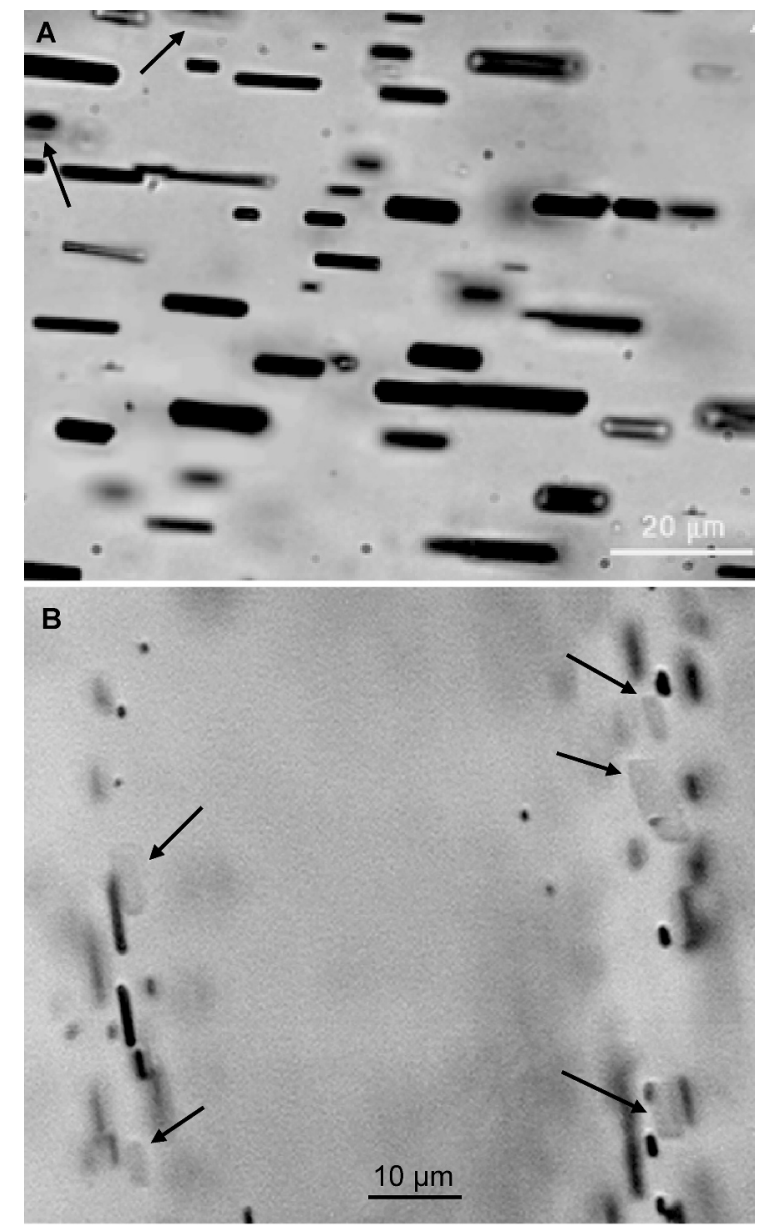

FIG. 5. Ilmenite and chromite precipitates in first-generation Alpe Arami olivine. A. Precipitates are commonly spatially random; ilmenite rods are oriented parallel to [010] of olivine; chromite platelets (difficult to see in this image ) are oriented parallel to (100) of olivine. Two chromites that are in focus and attached to ilmenite rods are indicated by arrows (see Dobrzhinetskaya et al., 1996; Green et al., 1997). B. Precipitates are in a few cases concentrated on (001) planes, but exhibit the same topotaxy as in A. In this image, virtually all ilmenite rods have a chromite platelet attached; arrows point out spinels without ilmenite (see Bozhilov et al., 2003). Figure 5A is modified after Figure 1 of Green et al. (1997); Figure 5B is modified after Figure 3C of Bozhilov et al. (2003).

but had been inferred to have developed at great depth (den Tex, 1971). To our surprise, we discovered that this generation of olivine also contained oriented inclusions of ilmenite, up to $>1 \%$ by volume in abundance (Fig. 5A). Our investigations determined that the ilmenite is topotactically related to the olivine, strongly suggesting an origin by exsolution from the olivine and therefore implying a $\mathrm{TiO}_{2}$ content of the olivine before exsolution of $>0.6$ wt. $\%$. Further examination determined that the same olivine grains also contain topotactically oriented chromite inclusions (Fig. 5B) with an estimated volume ratio to ilmenite of about 1:4 or 1:5. The observations can be quantitatively explained by the following chemical reaction:

$$
\begin{aligned}
& \mathrm{Fe}_{5}\left(\mathrm{Cr}, \mathrm{Fe}, \mathrm{Al}_{2}\right)_{2} \mathrm{Ti}_{4} \mathrm{O}_{16} \rightarrow 4 \mathrm{FeTiO}_{3}+\mathrm{Fe}\left(\mathrm{Cr}, \mathrm{Fe}, \mathrm{Al}_{2} \mathrm{O}_{4}\right. \text {, } \\
& \text { defect olivine } \rightarrow \text { ilmenite + chromite, }
\end{aligned}
$$

where $\Delta$ denotes an octahedral vacancy. The second generation of olivine was normal in every way; it contained no inclusions, displayed a normal LPO 
([010] normal to foliation), and was associated with interstitial ilmenite. It clearly formed by recrystallization of the earlier, ilmenite-bearing, generation under conditions of low ilmenite solubility during exhumation of the massif.

The strong indication that the ilmenite + chromite originated by exsolution created a considerable conceptual problem because olivine, although accepting Fe substitution for $\mathrm{Mg}$ in any proportion, accommodates virtually no other elements into solution except very small amounts of $\mathrm{Mn}$ and Ca. In particular, it essentially does not accept trivalent and tetravalent cations (e.g. Cr and Ti) into its structure. There are no published analyses of olivine with more than $\sim 500 \mathrm{ppm} \mathrm{Ti}$, with the highest concentrations from high-pressure mantle xenoliths (Hervig et al., 1986). We concluded that the most plausible conditions of origin were at depths greater than represented by the mantle xenolith suite, meaning depths of $\sim 300 \mathrm{~km}$ or more (Dobrzhinetskaya et al., 1996).

A firestorm of scientific criticism greeted publication of that Science paper (and its discussion worldwide in the popular press). A new circle of disbelief concerning UHPM was beginning. First, the experimental implications of glaucophane in blueschists were rejected because of the implications of depth and rates of burial and exhumation, implications explained by formulation of plate tectonics theory. Then coesite and diamond had been hard to accept because of their much greater depth implications, but once the presence of these minerals was demonstrated to be correct, only local pockets of entrenched resistance remained (discounting the arguments of tectonic overpressure which continue to be resurrected to this day). However, now a major jump in the depth from which rocks could be exhumed was being proposed, not based on a highpressure polymorph of known minimum depth implications, but based on chemical evidence without pre-existing experimental demonstration that the hypothesis was at least possible.

Realizing that such skepticism would be a reasonable response of the community, especially given the history of UHPM denial, even before publication of this paper we had secured funding to test whether this radical suggestion could be correct. We initiated a high-pressure research program to investigate whether there are any conditions under which olivine can dissolve $>0.6 \mathrm{wt} \% \mathrm{TiO}_{2}$ and, if so, to map out those conditions. We determined (to our own surprise) that there are conditions where the solubility of $\mathrm{TiO}_{2}$ in olivine is sufficient to explain the observations in Alpe Arami, but only at pressures of 9-12 $\mathrm{GPa}$, depending on temperature (Dobrzhinetskaya et al., 2000). The explanation appears to be that the solubility of $\mathrm{TiO}_{2}$ in olivine is significantly enhanced when the pressure becomes sufficiently high to stabilize $\mathrm{Ti}$ in the tetrahedral site of the olivine crystal structure. However, as had occurred earlier concerning Smith's discovery of coesite in Norway, the criticism had taken on a life of its own and demonstration that the intepretation was viable seemingly had no effect at all on the scientific community. In response, we reinvestigated several aspects of the study and showed that our original interpretation of the amount of $\mathrm{TiO}_{2}$ previously in solution was correct and that the high-pressure interpretation is the only one consistent with all of the observations (Bozhilov et al., 2003). In particular, we showed that an alternative interpretation that the ilmenite could have arisen from dehydration of titanian clinohumite (Risold et al., 2001) is incompatible with the presence of co-precipitated ilmenite + chromite.

Moreover, as the firestorm over Alpe Arami olivine was expanding, we were already finding that diopside inclusions in garnet of these same rocks contain exsolution lamellae of clinoenstatite (technically pigeonite, because of small Ca content) displaying antiphase domains that indicate the originally precipitated pyroxene had the $\mathrm{C} 2 / \mathrm{c}$ space group (Fig. 6). There are two C2/c clinopyroxene phases that could fulfill this observation: high-temperature clinoenstatite and high-pressure clinoenstatite. From the totality of our observations, we concluded that the $\mathrm{C} 2 / \mathrm{c}$ precursor had to be the high-pressure variety, providing an independent constraint of greater than $\sim 8 \mathrm{GPa}(\sim 250 \mathrm{~km})$ for origin of the Alpe Arami peridotite (Bozhilov et al., 1999). The alternative interpretation, that the $\mathrm{C} 2 / \mathrm{c}$ precursor could have been high-temperature clinoenstatite metastably exsolved in the orthopyroxene stability field (Arlt et al., 2000), is inadequate because: (1) it would require temperatures at least $200^{\circ} \mathrm{C}$ higher than the Alpe Arami exhumation curve derived by others (Brenker and Brey, 1997); (2) it is incompatible with the crystallographic orientation of the lamellae within diopside; (3) existing phase diagrams show that low-pressure exsolution of clinoenstatite from diopside is inconsistent with the very high Mg content of the lamellae. Finally, recent discovery (Liu et al., 2005) of essentially identical C2/c clinoenstatite/pigeonite exsolution lamellae 

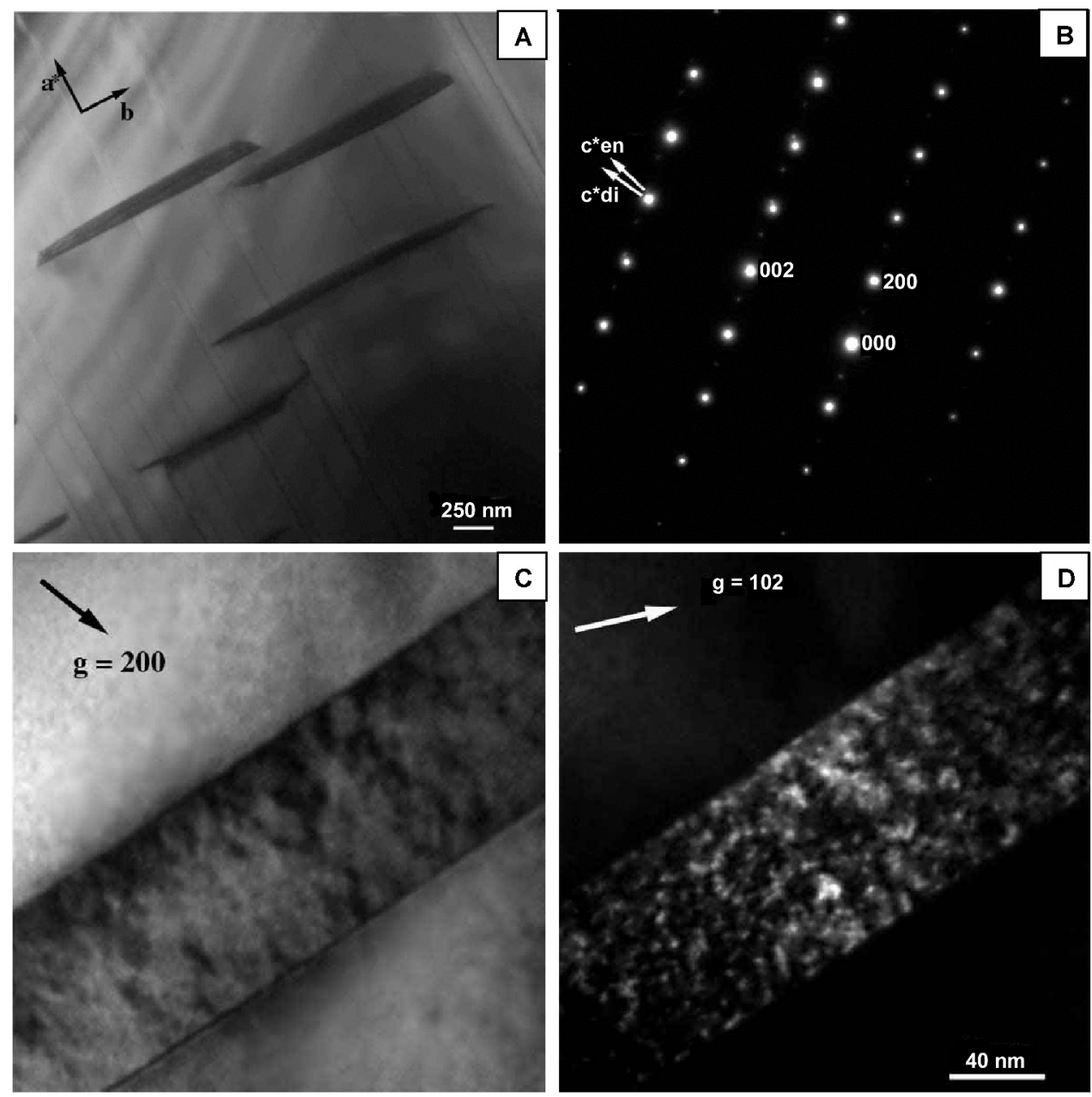

FIG. 6. Exsolution of high-pressure clinoenstatite/pigeonite from diopside. A. Low-magnification bright-field image of lamellae. B. Selected-area diffraction pattern showing spots of both diopside and (low) clinoenstatite. C. Dark-field image of a single lamella showing strain mottling due to inversion from the denser C2/c form. D. Dark-field image of same lamella, same area, under different diffraction conditions, showing antiphase domains (bright) recording the former presence of the $\mathrm{C} 2 / \mathrm{c}$ form.

from diopside in the Dabie UHPM belt of eastern China, a terrane with a much colder exhumation curve than Alpe Arami, confirms that such exsolution lamellae in garnet peridotite represent highpressure clinoenstatite/pigeonite (in addition to establishing a higher than thus-far-accepted depth of exhumation for that eastern China UHPM belt). Lastly, the conditions necessary to account for the $\mathrm{TiO}_{2}$-in-olivine observations are incompatible with the conditions necessary to explain away the highpressure C2/c pyroxene, and vice-versa, yet both can be found repeatedly in the same thin section.
In summary, exsolution of oxides in olivine and of high-pressure pyroxenes in diopside, coupled with experimental determination of the $\mathrm{P} / \mathrm{T}$ dependence of solubility of $\mathrm{TiO}_{2}$ in olivine and the thermobarometry of others, demonstrate that the Alpe Arami garnet peridotite carries memory of a previous equilibration at a depth in excess of $\sim 300 \mathrm{~km}$ (Fig. 7). The body was transported to the surface during the later stages of the Alpine collision between Europe and Africa, presumably buoyantly uplifted by the quartzofeldspathic Lepontine gneisses in which it is found (but which so far have 


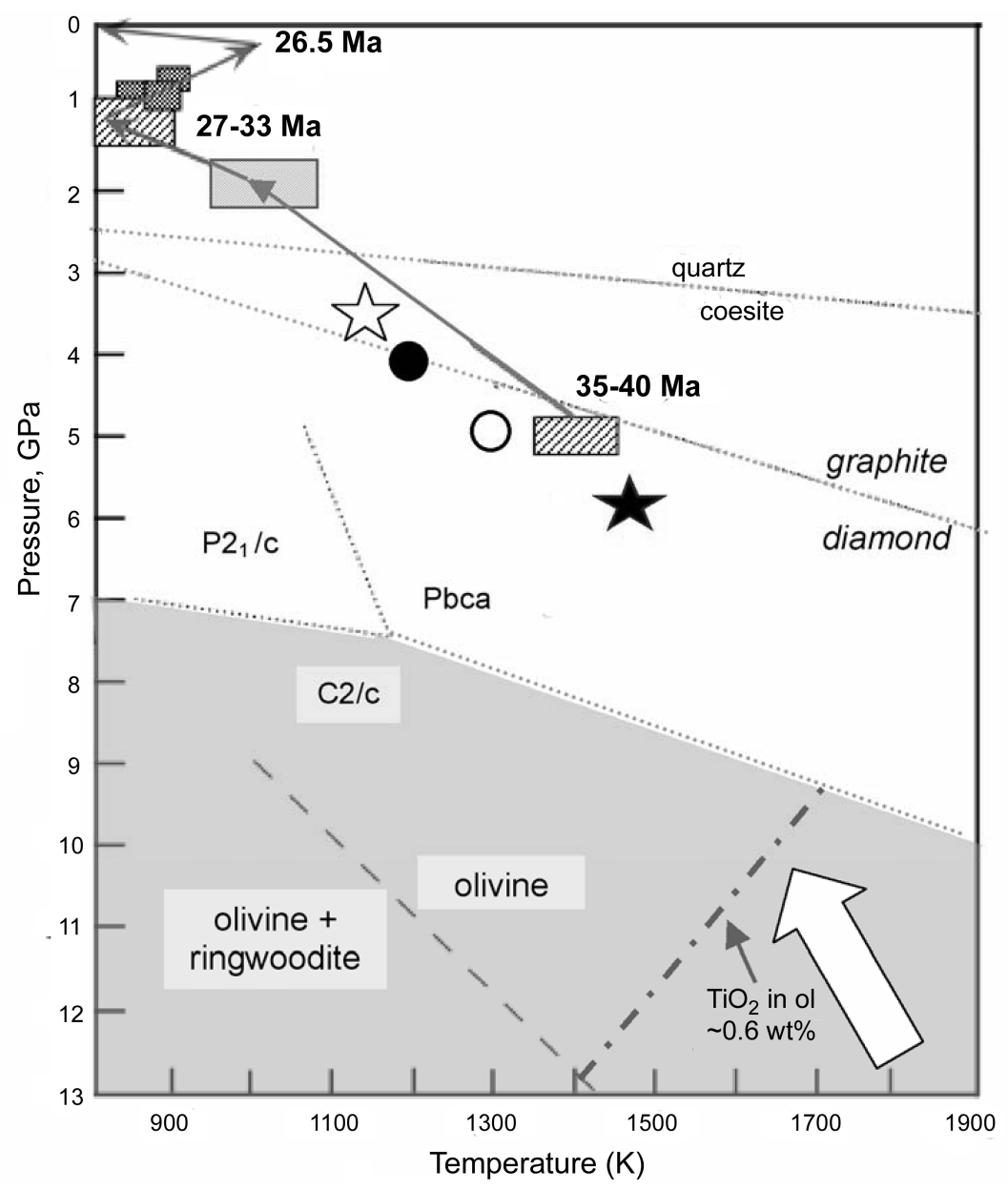

FIG. 7. Exhumation path for the Alpe Arami peridotite. Five thermobarometric studies have been published on the Alpe Arami peridotite. The maximum pressure/temperature points calculated by Ernst (1978), Medaris and Carswell (1990), Paquin and Alther (2001a), and Nimis and Trommsdorff (2001a) are shown by a solid circle, open circle, solid star, and open star, respectively. A more ambitious study by Brenker and Brey (1997) derived several points along the exhumation path by careful examination of microstructural relationships and associated chemical inhomogeneities (hatchured boxes connected by arrows). Three points along this path are labeled with dates estimated by these authors to correspond with points they derived. In addition, we plot (1) the quartz/coesite and graphite/diamond phase boundaries as well as the equilibrium boundaries between the three principal phases of $\mathrm{Mg}_{0.9} \mathrm{Fe}_{0.1} \mathrm{SiO}_{3}$ (i.e., low clinoenstatite, space group P2 $/ \mathrm{c}$; orthoenstatite, space group Pbca; high-pressure clinoenstatite/pigeonite, space group C2/c); (2) the reaction boundary of olivine to olivine + ringwoodite (dashed line); (3) the approximate set of conditions under which olivine can dissolve a minimum of $0.6 \mathrm{wt} \% \mathrm{TiO}_{2}$ (dot-dashed line). The combination of the observations on olivine and diopside described here require that the exhumation path for the Alpe Arami peridotite passes through the shaded region to the right of the dot-dashed line (block arrow).

not yielded direct evidence of very high pressures). Whether this was a single-stage exhumation directly from $>300 \mathrm{~km}$ along the Alpine subduction zone or whether a more complicated history is involved is still not known.

\section{The Caledonides}

While the controversy concerning Alpe Arami was in full bloom, another remarkable discovery was made in the Western Gneiss Region of Norway. The 



FIG. 8. Precipitation of pyroxenes in garnet. A. Grain-boundary precipitates of enstatite (enst) in garnet nodule of peridotite, Western Gneiss Region, Norway. Such nodules also display typical exsolution lamellae of enstatite in the centers of garnets greater than $4 \mathrm{~mm}$ diameter (see van Roermund and Drury, 1998). B. Similar precipitates produced in an experiment first equilibrated at $8 \mathrm{GPa}$, in which all enstatite dissolved and then held at the same temperature and 5 GPa to exsolve enstatite (Dobrzhinetskaya et al., 2004). Note difference of $10^{3}$ between scale bars in A and B. C. Optical micrograph (crossed polarizers) of sodic diopside (now mostly altered to amphibole) along grain boundaries in garnet nodule of Alpe Arami peridotite, Switzerland. Insert is SEM image of a diopside relic in amphibole showing exsolution lamellae of quartz and an earlier amphibole of different composition (Green and coworkers, unpubl. results). D. Diopside along grain boundaries in garnet nodule of Sulu peridotite, China (Dobrzhinetskaya and Green, unpubl. results).

garnet harzburgites abundant in that terrane in many places contain large $(>10 \mathrm{~mm})$ purple garnets. Microscopic examination of such garnets showed them to be polycrystalline. Individual garnets with diameters $>4 \mathrm{~mm}$ were found to contain in their cores abundant exsolution lamellae of enstatite, with minor exsolution of diopside; the rims of these grains were clear of pyroxene, as were the entirety of smaller garnets, but all of the triple junctions between garnets (and many grain boundaries) con- tained enstatite crystals (Fig. 8A). This classic exsolution microstructure showed that these garnets had contained a significant majoritic component, implying depths in excess of $200 \mathrm{~km}$ (van Roermund and Drury, 1998). This microstructure had been reported previously in xenoliths from kimberlite (Haggerty and Sautter, 1990; Sautter et al., 1991) and is consistent with the experimentally well-documented progressive dissolution of pyroxenes into garnet with increasing pressure (e.g., Ringwood, 
1991). We have tested this concept in the laboratory by first dissolving significant enstatite into garnet at $8 \mathrm{GPa}$ and then re-equilibrating the specimen at 5 $\mathrm{GPa}$, precipitating enstatite along grain boundaries (Fig. 8B; see also Dobrzhinetskaya et al., 2004). Other polycrystalline garnets in peridotites worldwide show inclusions of diopside along grain boundaries, suggesting much higher pressures, because diopside goes into garnet in significant amounts only at higher pressures than enstatite. Examples from Alpe Arami, Switzerland and the SuLu belt of eastern China are given in Figures 8C and 8D. We have also verified experimentally that majoritic garnet grown at $14 \mathrm{GPa}$ exsolves diopside at grain boundaries at pressures of 10-12 GPa (not shown). Future work is necessary, however, to demonstrate that the experimental studies are fully consistent with observations on natural peridotites.

Van Roermund and Drury (1998) attributed the exsolution of pyroxene in garnet in Norway to a preCambrian diapiric event unrelated to Caledonian subduction, with subsequent storage in the upper mantle until the peridotites were exhumed along with the Caledonian UHPM rocks. The previous widely accepted experimental work and presence of the microstructure in xenoliths, coupled with an interpretation placing the exsolution event prior to the Caledonian orogeny, made acceptance of this discovery almost instantaneous, despite the only recently terminated denial of coesite and continuing denial of diamond in this terrane. Similar microstructures involving interstitial diopsides in polycrystalline garnets from other terranes, including Alpe Arami and eastern China, are suggestive of even greater depths, but sorting out the meaning of those microstructures remains for future work.

More recently (van Roermund et al, 2002), microdiamonds have been discovered within similar peridotites on the same island (Fjortoft) where the original Norwegian diamond discovery had been made in Caledonian metasediments (Dobrzhinetskaya et al., 1995). Hence that controversy has also been put to rest.

\section{Eastern China}

Thus far, only brief mention has been made of the Chinese UHPM belt of the Dabie Mountains and the Sulu terrane. Although less prominent in the controversies in the literature, this belt has steadily increased in importance for several reasons. Firstly, it is by far the largest UHPM terrane; it is now known to be comprised of at least two UHPM events separated by $\sim 200$ m.y. in age and extending more than $4000 \mathrm{~km}$ across China in an approximately E$\mathrm{W}$ orientation (Yang et al., 2003), with coesite and diamond occurrences sprinkled along its length. The Chinese belt has another very important feature. Through systematic extraction and analysis of zircons from the continental country rocks in which the eclogites and peridotites are embedded, it has been abundantly and unequivocally demonstrated that these rocks all contain coesite (Ye et al., 2000). Thus, it is clear that the mafic and ultramafic rocks have not been exhumed from great depth and tectonically emplaced within the continental gneisses in which they are found, but that the continental gneisses were also subducted to and exhumed from great depth. Only within zircons have these rocks retained their "memory" of the voyage, because the bulk rocks are less refractory and have efficiently back-reacted to lower-pressure assemblages during the return trip. The nonreactive zircons, with their broad stability range, have served as almost perfect environmental capsules, and withstood the exhumation without breaking down or allowing their contents to be back-reacted. As mentioned above, discovery of coesite in the country gneisses of Norway (Wain, 1997) demonstrated similar bulk subduction and exhumation. In both cases, recognition that the country gneisses were also deeply subducted then provides a ready explanation for the UHPM mafic and ultramafic rocks within them. They were simply emplaced together after exhumation. The strikingly similar deformation microstructures and migmatization common in the quartzofeldspathic gneisses of other UHPM terranes strongly suggests that these gneisses, too, have experienced the two-way street of subduction during continental collision, despite the current lack of positive confirmation within them. As has become the pattern, this argument is controversial in every place where it has not been proven (e.g., in the western Alps), yet no alternative reasonable explanation of how the UHPM rocks in these terranes could have been transported to the surface and emplaced in their present positions has been offered.

The Chinese UHPM belt also has some other specific characteristics that make it particularly interesting. First, oxygen isotope ratios are extremely light (Rumble et al., 2002), implying arctic subduction or perhaps a manifestation of the extraordinary glacial conditions in the late Precambrian (interpreted as "snowball earth" by some 
authors). Second, extraordinary amounts of magnetite are found in olivine of some localities, seemingly in exsolution relationship to the olivine. It has been suggested (Zhang et al., 1999) that this microstructure could imply extensive solid solution between magnetite and the post-olivine phases of the mantle transition zone (wadsleyite with a spineloid structure or ringwoodite with a true spinel structure), implying the greatest depth of exhumation yet proposed. The remarkably fresh nature of many of the eclogites and peridotites (e.g., Fig. 8D) and the $5 \mathrm{~km}$ drill hole in progress in Sulu (Xu et al., 2004) allows the prospect of more exciting discoveries to come.

Lastly, chromite deposits of the Luobosa ophiolite of Tibet contain diamonds and moissanite (SiC), and have been argued to contain minerals from the mantle transition zone, the lower mantle, and perhaps even the core-mantle boundary (Bai et al., 2004). This deposit appears to be igneous, and therefore different from UHP metamorphism. However the pattern of denial so consistently applied to UHPM discoveries has fallen very hard on these descriptions. Perhaps rightly so, but stay tuned....

\section{Conclusions and Psychoanalysis}

I conclude that the saga of ultrahigh-pressure metamorphism is probably in its young adulthood or, perhaps, still only at the end of its childhood. It has been a relatively slow revolution, with its principal punctuations being Ernst (1963), Ernst (1978), Chopin (1984) and Smith (1984), Sobolev and Shatsky (1990), and Dobrzhinetskaya et al. (1996). In each case, a powerful new set of observations was added to the fabric of metamorphic petrology: The first two were due to initial applications of new experimental advances, the third and fourth were field-based (but with experimental backing required for the stability range of the high pressure polymorphs discovered), and the fifth, based on microstructures, required subsequent experimental verification to be viable.

Was the slow and grudging acceptance of each forward step in this new field of metamorphic petrology a drama of human resistance to a changing paradigm, or is this just a good example of science working in the conservative way it must? I see strong examples of both in the sometimes intellectual, sometimes emotional, debates that have ensued for 40 years. It will be great fun to watch over the next
10 years as new gems are added to the crown of UHPM.

\section{Acknowledgments}

I thank Gary Ernst for many years of inspiration and many of those cited here for their perseverance in the face of emotional and financial discouragement. I also thank Y. Seki for the image in Figure 1, Claude Chopin for Figure 3A; David Smith for Figure 3B; Larissa Dobrzhinetskaya for Figures 4A, 4B, 4C, 4F, and 8D; Herman van Roermund for Figures 4D and 8A; and Jingsui Yang for Figure 4E. I also thank Larissa Dobrzhinetskaya and Junfeng Zhang for helpful reviews. My own work discussed in this paper was supported by various grants from the U.S. National Science Foundation.

\section{REFERENCES}

Arlt, Th., Kunz, M., Stolz, J., Armbruster, Th., and Angel, R. J., 2000, P-T-X data on P21/c-clinopyroxenes and their displacive phase transitions: Contributions to Mineralogy and Petrology, v. 138, p. 35-45.

Bai, W., Robinson, P., Fang, Q.-S., Malpas, J., Yang, J.-S., Zhou, M.-F., Hu, X.-F., 2004, Silicon spinel—an ultrahigh pressure mineral recovered from podiform chromitites of the Luobusa ophiolite, Tibet: 32nd International Geological Congress, Florence, Italy, Abs. Vol., pt. 1, p. 720 (abs. \#153-6).

Bostick, B. C., Jones, R. E., Ernst, W. G., Chen, C., Leech, M. L., and Beane, R. J., 2003, Low-temperature microdiamond aggregates in the Maksyutov Metamorphic Complex, South Ural Mountains, Russia: American Mineralogist, v. 88,p. 1709-1717.

Boyd, F. R., 1973, A pyroxene geotherm: Geochimica et Cosmochimica Acta, v. 37, p. 2533-2546.

Bozhilov, K. N., Dobrzhinetskaya, L. F., and Green, II, H. W., 2003, Quantitative 3D measurement of ilmenite abundance in Alpe Arami olivine: Confirmation of high pressure origin: American Mineralogist, v. 88, p. 596-603.

Bozhilov, K. N., Green, H. W., II, and Dobrzhinetskaya, L., 1999, Clinoenstatite in Alpe Arami peridotite: Additional evidence for very high pressure: Science, v. 284, p. 128-132.

Brace, W. F., Ernst, W. G., and Kallberg, R. W., 1970, An experimental study of tectonic overpressure in Franciscan rocks: Geological Society of America Bulletin, v. 81, p. 1325-1338.

Brenker, F. E., and Brey, G. P., 1997, Reconstruction of the exhumation path of the Alpe Arami garnet-peridotite body from depths exceeding $160 \mathrm{~km}$ : Journal of Metamorphic Geology, v. 15, p. 581-592. 
Buiskool Toxopeus, J. M. A., 1976, Petrofabrics, microstructures, and dislocation substructures of olivine in peridotite mylonite (Alpe Arami, Switzerland): Leidse Geol. Med., v. 51, p. 1-36.

Buiskool Toxopeus, J. M. A., 1977, Fabric development of olivine in a peridotite mylonite: Tectonophysics, 1977, v. 39 , p. $55-71$.

Chao, E. C.-T., Shoemaker, E. M. J., and Madsen, B. M., 1960, First natural occurrence of coesite [Arizona]," Science, v. 132, p. 220-222.

Chopin, C., 1984, Coesite and pure pyrope in high-grade blueschists of the western Alps: A first record and some consequences: Contributions to Mineralogy and Petrology, v. 86, p. 107-118.

Collinson, D. W., and Runcorn, S. K., 1960, Polar wandering and continental drift-evidence from paelomagnetic observations in the United States: Geological Society of America Bulletin, v. 71, p. 915-958.

den Tex, E., 1971, Age, origin, and emplacement of some alpine peridotites in the light of recent petrofabric researches: Fortschrift Mineralogie, v. 48, p. 69-74.

Dobrzhinetskaya, L. F., Bozhilov, K. N., and Green, H. W., II, 2000, The solubility of $\mathrm{TiO}_{2}$ in olivine: Implications for the mantle wedge environment: Chemical Geology, v. 163 , p. $325-338$.

Dobrzhinetskaya, L. F., Eide, E. A., Larsen, R. B., Sturt, B. A., Tronnes, R. G., Smith, D. C., Taylor, W. R., and Posukhova, T. V., 1995, Microdiamond in high-grade metamorphic rocks of the Western Gneiss Region, Norway: Geology v. 23, p. 597-600.

Dobrzhinetskaya, L.F., Green, H. W., II, Mitchell, T., and Dickerson, R. M., 2001, Metamorphic diamonds: Mechanism of growth and inclusion of oxides: Geology, v. 29 , p. 263-266.

Dobrzhinetskaya, L. G., Green, H. W., II, Renfro, A. P., Bozhilov, K. N., Spengler, D., and van Roermund, H. L. M., 2004, Precipitation of pyroxenes and olivine from majoritic garnet: Simulation of peridotite exhumation from great depth: Terra Nova, v. 16, p. 325330.

Dobrzhinetskaya, L. F., Green, H. W., II, and Wang, S., 1996, Alpe Arami: A peridotite massif from depths of more than 300 kilometers: Science, v. 271, p. 18411845.

Ernst, W. G., 1963, Petrogenesis of glaucophane schists: Journal of Petrology, v. 4, p. 1-30.

Ernst, W. G., 1965, Mineral paragenesis in Franciscan metamorphic rocks, Panoche Pass, California: Geological Society of America Bulletin, v. 76, p. 879-914.

Ernst, W. G., 1978, Petrochemical study of lherzolitic rocks from the Western Alps: Journal of Petrology, v. 19 , p. 341-392.

Gibbs, J. W., 1948, On the equilibrium of heterogeneous substances, in Collected works of J. Willard Gibbs: New Haven, CT, Yale University Press, p. 55-371.
Green, H. W., II, 1970, Diffusional flow in polycrystalline materials: Journal of Applied Physics, v. 41, p. 3899 3902.

Green, H. W., II, 1980, On the thermodynamics of nonhydrostatically stressed solids: Philosophical Magazine, v. A41, p. 637-647.

Green, H. W., II, 1986 Phase transformation under stress and volume transfer creep, in Hobbs, B. E., and Heard, H. C., eds., Mineral and rock deformation: Laboratory studies-the Paterson volume: Washington, DC, American Geophysical Union, Geophysical Monograph, v. 36, p. 201-211.

Green, H. W., II, Dobrzhinetskaya, L., and Bozhilov, K., 1997, Determining the origin of ultra-high pressure lherzolites (response): Science, v. 278, p. 704-707.

Green, H. W., II, and Gueguen, Y., 1974 Origin of kimberlite pipes by diapiric upwelling in the upper mantle: Nature, v. 249, p. 617-620.

Haggerty, S. E., and Sautter, V., 1990, Ultra-deep (>300 $\mathrm{km})$ ultramafic, upper mantle xenoliths: Science v. 248, p. 993-996.

Hervig, R. L., Smith, J. V., and Dawson, J. B., 1986, Lherzolite xenoliths in kimberlites and basalts: Petrogenetic and crystallochemical significance of some minor and trace elements in olivine, pyroxenes, garnets, and spinel: Royal Society of Edinburgh Transactions, Earth Sciences, v. 77, p. 181-201.

Hess, H. H., and Revelle, R., 1963, The origins of the continents, oceans, and atmosphere, in The scientific endeavor-centennial celebration of the National Academy of Sciences: New York, NY, Rockefeller Institute Press.

Holmes, A., 1965, Principles of physical geology, rev. ed.: New York, NY, Ronald Press.

Isaacs, B., Oliver, J., and Sykes, L. R., 1968, Seismology and the new global tectonics: Journal of Geophysical Research, v. 73, p. 5855-5899.

Kamb, W. B., 1961a, The thermodynamic theory of nonhydrostatically stressed solids: Journal of Geophysical Research, v. 66, p. 259-271.

Kamb, W. B., 1961b, Author's reply to discussions of the paper "The thermodynamic theory of nonhydrostatically stressed solids," Journal of Geophysical Research, v. 66, p. 3985-3988.

Le Pichon, X., 1968, Sea-floor spreading and continental drift: Journal of Geophysical Research, v. 73, p. 36613697.

Liu, X.-W., Jin, Z.-M., Green, H. W., II, and Qu, J., 2005, Clinoenstatite exsolution in diopside of garnet lherzolite from Bixiling massif of Dabie mountains and its geological significance (submitted).

MacDonald, G. J. F., 1961, Discussion of paper by W. Barclay Kamb, "The thermodynamic theory of nonhydrostaticallly stressed solids," Journal of Geophysical Research, v. 66, p. 2599.

Massonne, H.-J., 1999, A new occurrence of microdiamonds in quartzofeldspathic rocks of the Saxonian 
Erzgebirge, Germany, and their metamorphic evolution, in Nixon, P. H., ed., Proceedings of VIIth International Kimberlite Conferrence-1998. Cape Town, South Africa, p. 533-539.

Medaris, L. G., and Carswell, D. A., 1990, The petrogenesis of $\mathrm{Mg}$-Cr garnet peridotites in European metamorphic belts, in Carswell, D. A., ed., Eclogite facies rocks: Glasgow-London, UK, Blackie, p. 260-290.

Möckel, J. R., 1969, Structural petrology of the garnet peridotite of Alpe Arami (Ticino, Switzerland). Leidse Geol. Med., v. 42, p. 61-130.

Morgan, W. J., 1968, Rises, trenches, great faults and crustal blocks: Journal of Geophysical Research, v. 73, p. 1959-1982.

Mposkos, E. D., and Kostopoulos, D. K., 2001, Diamond, former coesite, and supersilicic garnet in metasedimentary rocks from the Greek Rhodope: A new ultrahigh-pressure metamorphic province established: Earth and Planetary Science Letters, v. 192, p. 497506.

Nasdala, L., and Massonne, H.-J., 2000, Microdiamonds from the Saxonian Erzgebirge, Germany: In situ microRaman characterisation: European Journal of Mineralogy, v. 12, p. 495-498.

Nimis, P., and Trommsdorff, V., 2001a, Revised thermobarometry of Alpe Arami and other garnet peridotites from the Central Alps: Journal of Petrology, v. 42, p. 103-115.

Nimis, P., and Trommsdorff, V., 2001b, Comment on "New constraints on the P-T evolution of the Alpe Arami garnet peridotite body (Central Alps, Switzerland)" by Paquin \& Altherr (2001): Journal of Petrology, v. 42, p. 1773-1779.

Ogasawara, Y., Fukasawa, K., and Maruyama, S., 2002, Coesite exsolution from supersilicic titanite in UHP marble from the Kokchetav Masssif, northern Kazakhstan: American Mineralogist, v. 87, p. 454-4361.

Opdyke, N. D., and Runcorn, S. K., 1956, New evidence for reversal of the geomagnetic field near the Pliocene-Pleistocene boundary: Science, v. 123, p. 1126-1127.

Paquin, J., and Altherr, R., 2001a, New constraints on the P-T evolution of the Alpe Arami garnet peridotite body (Central Alps, Switzerland): Journal of Petrology, v. 42, p. 1119-1140.

Paquin, J., and Altherr, R., 2001b, "New constraints on the P-T evolution of the Alpe Arami garnet peridotite body (Central Alps, Switzerland)": Reply to comment by Nimis \& Trommsdorff (2001): Journal of Petrology, v. 42 , p. 1781-1787.

Parkinson, Ch., and Katayama, I., 1999, Metamorphic diamond and coesite from Sulawesi, Indonesia: Evidence of deep subduction at the SE Sundaland margin: EOS (Transactions of the American Geophysical Union), v. 80, no. 46, p. 1181.

Ringwood, A. E., 1991, Phase transformations and their bearing on the constitution and dynamics of the man- tle: Geochimica et Cosmochimica Acta, v. 55, p. 2083 2110.

Risold, A.-C., Trommsdorff, V., and Grobéty, B., 2001, Genesis of ilmenite rods and palisades along humitetype defects in olivine from Alpe Arami: Contributions to Mineralogy and Petrology, v. 140, p. 619-628.

Rumble, D., Giorgis, D., Ireland, T., Zhang, Z. M., Xu, H. F., Yui, T. F., Yang, J. S., Xu, Z. Q., and Liou, J. G., 2002, Low delta O-18 zircons, U-Pb dating, and the age of the Qinglongshan oxygen and hydrogen isotope anomaly near Donghai in Jiangsu Province, China: Geochimica et Cosmochimica Acta, v. 66, p. 2299 2306.

Sautter, V., Haggerty, S. E., and Field S., 1991, Ultra-deep $(>300 \mathrm{~km})$ ultramafic xenolith: New petrologic evidence from the transition zone: Science, v. 252, p. 827-830.

Smith, D. C., 1984, Coesite in clinopyroxene in the Caledonides and its implications for geodynamics: Nature, v. 310, p. 641-644.

Smyth, J. R., and Hatton, C. J., 1977, A coesite-sanidine grospydite from the Roberts-Victor kimberlite: Earth and Planetary Science Letters, v. 34, p. 284-290.

Sobolev, N., and Shatsky, V., 1990, Diamond inclusions in garnets from metamorphic rocks: A new environment of diamond formation: Nature, v. 343, p. 742-746.

van Roermund, H. M., and Drury, M. R., 1998, Ultra-high pressure $(\mathrm{P}>6 \mathrm{GPa})$ garnet peridotites in Western Norway: Exhumation of mantle rocks from $>185 \mathrm{~km}$ depth: Terra Nova, v. 10, p. 295-301.

van Roermund, H. L. M., Carswell, D. A., Drury, M. R., and Heijboer, T. C., 2002, Microdiamonds in megacrystic garnet websterite pod from Bardane on the island of Fjortoft, western Norway: Evidence for diamond formation in mantle rocks during deep continental subduction. Geology, v. 30, p. 959-962.

Vaughan, P. J., Green, H. W., II, and Coe, R. S., 1984, Anisotropic growth in the olivine-spinel transformation of $\mathrm{Mg}_{2} \mathrm{GeO}_{4}$ under nonhydrostatic stress: Tectonophysics, v. 108, p. 299-322.

Vine, F. J., and Matthews, D. H., 1963, Magnetic anomalies over oceanic ridges: Nature, v. 199, p. 947-949.

Wain, A., 1997, New evidence for coesite in eclogite and gneisses: Defining an ultrahigh-pressure province in the Western Gneiss region of Norway: Geology, v. 25, p. 927-930.

Wang, X., Liou, J. G., and Mao, H. K., 1989, Coesite-bearing eclogites from the Dabie Mountains in central China: Geology, v. 17, p. 1085-1088.

Wegener, A., 1912, Die Entestehung der kontinente: Geologische Rundschau, v. 3, p. 276-292.

Wegener, A., 1923, The origin of continents and oceans (translated from the third German edition by J. G. A. Skerl). New York, NY, E.P. Dutton \& Co.

Wilson, J. T. 1963, A possible origin of the Hawaiian Islands: Canadian Journal of Physics, v. 41, p. 863 870 . 
Wilson, J. T., 1965, A new class of faults and their bearing on continental drift: Nature, v. 207, p. 343-347.

Xu, S., Okay, A. L., Sengor, A., Su, W., Liu, Y., and Jiang, L., 1992, Diamond from the Dabie Shan metamorphic rocks and its implication for tectonic setting: Science, v. 256, p. $80-82$.

Xu, Z., 2004, 32nd International Geological Congress, Florence, Italy, Abs. Vol., pt. 1, p. 723 (abs. \#153-17).

Yang, J., Xu, Z., Dobrzhinetskaya, L. F., Green, H. W., II, Pei, X., Shi, R., Wu, C., Wooden, J. L., Zhang, J., Wan, Y., and Li, H., 2003, Discovery of metamorphic diamonds in central China: an indication of a $>4000$ $\mathrm{km}$-long zone of deep subduction resulting from multi- ple continental collisions: Terra Nova [doi: 10.1046/ j.1365-3121.2003.00511.x].

Ye, K., Yao, Y. P., Katayama, I., Cong, B. L., Wang, Q. C., and Maruyama, S., 2000, Large areal extent of ultrahigh-pressure (UHP) metamorphism in the Sulu ultrahigh-pressure terrane of East China: New implications from coesite and omphacite inclusions in zircon of granitic gneiss: Lithos, v. 52, p. 157-164.

Zhang R. Y., Shu, J. F., Mao, H. K., and Liou, J. G., 1999, Magnetite lamellae in olivine and clinohumite from Dabie UHP ultramafic rocks, central China: American Mineralogist, v. 84, p. 564-569. 